\begin{tabular}{c|c|c}
\hline \hline & DISEASES OF AQUATIC ORGANISMS \\
Vis Aquat Org & Do: 35-43, 2002 & Published June 21 \\
\hline
\end{tabular}

\title{
Vibrio carchariae, a pathogen of the abalone Haliotis tuberculata
}

\author{
J. L. Nicolas ${ }^{1, *}$, O. Basuyaux ${ }^{2}$, J. Mazurié ${ }^{3}$, A. Thébault ${ }^{4}$ \\ ${ }^{1}$ Laboratoire de Physiologie des Invertébrés, Institut Francais de Recherche pour l'Exploitation de la Mer (IFREMER), \\ BP 70, 29280 Plouzané, France \\ ${ }^{2}$ Syndicat Mixte pour l'Equipement du Littoral (SMEL), Zac de Blainville, 50600 Blainville-sur-Mer, France \\ ${ }^{3}$ Laboratoire de Conchylicole de Bretagne, Institut Francais de Recherche pour l'Exploitation de la Mer (IFREMER), \\ 12 Rue des Résistants, BP 86, 56470 La Trinité-sur-Mer, France \\ ${ }^{4}$ Laboratoire de Génétique Pathologie, Institut Francais de Recherche pour l'Exploitation de la Mer (IFREMER), \\ BP 133, 17390 La Tremblade, France
}

\begin{abstract}
Since 1997, mass mortality of the abalone Haliotis tuberculata L. has occurred in the natural environment along the French coast. The outbreak of disease started on the south coast of Brittany near Concarneau in 1997, then spread to the north of Brittany (in 1998) and the west coast of Normandy (Golfe de St. Malo in 1999). Between 60 and $80 \%$ of the abalone died. In 1999, mortality also affected a land-based abalone farm in Normandy during the summer. At this farm, a Vibrio sp. was isolated in abundance from abalone that had just died. The disease was experimentally reproduced by inoculation or by introducing the pathogen into the surrounding water. This vibrio, identified by genotypic and phenotypic characters, is related to $V$. carchariae. It is similar to the $V$. carchariae, responsible for mortality in the Japanese abalone Sulculus diversicolor supratexta, but some phenotypic characters differentiate both strains. In 2000, healthy abalone placed in 2 sites on the north and south coasts of Brittany died, and the pathogen $V$. carchariae could be isolated from dead individuals, demonstrating that the pathogen was probably the cause of the abalone disease that has been occurring since 1997 in Brittany.
\end{abstract}

KEY WORDS: Haliotis tuberculata Vibrio carchariae Bacterial epizootic $\cdot$ Pathogenicity Resale or republication not permitted without written consent of the publisher

\section{INTRODUCTION}

The European abalone Haliotis tuberculata can be found from the north of France to Senegal. The population is relatively scattered. Since 1995, a dive fishery has been permitted on the Brittany and Normandy coasts of France. In 1997, $97 \mathrm{t}$ were fished and exported, mainly to the Far East and Middle East. At the same time, a regional company (SMEL) developed artificial production of this abalone (Basuyaux 1997). Several hundred kilograms were produced and sold commercially.

For several years, mass mortalities have been observed in the natural environment. In 1997, mortality affected stocks south of Brittany, near Concarneau

*E-mail: jlnicola@ifremer.fr
(Fig. 1), and in 1998 mortality spread to the north of Brittany from Saint Malo to Erquy, where about $80 \%$ of the abalone died. In 1999 mortality spread further north in the Golfe de St. Malo (Fig. 1) towards the Islands of Chausey and Jersey (50 to $90 \%$ mortality), the Minquiers near Jersey (70\% mortality) and also to the farm of SMEL, Blainville (85\% mortality). Now, only a few areas remain unaffected. Until now no such mass mortalities have affected abalone in France, except in 1960 when a very cold winter was the cause.

The observation of moribund abalone in the natural environment in France has been difficult. Diseased abalone are eaten by predators and generally only the empty shells have given evidence of mortality. In the SMEL abalone farm, mortality started in the middle of July and affected all sizes of abalone from $0.5 \mathrm{~cm}$ up. Fifty percent died within $2 \mathrm{wk}$ and cumulative mortal- 


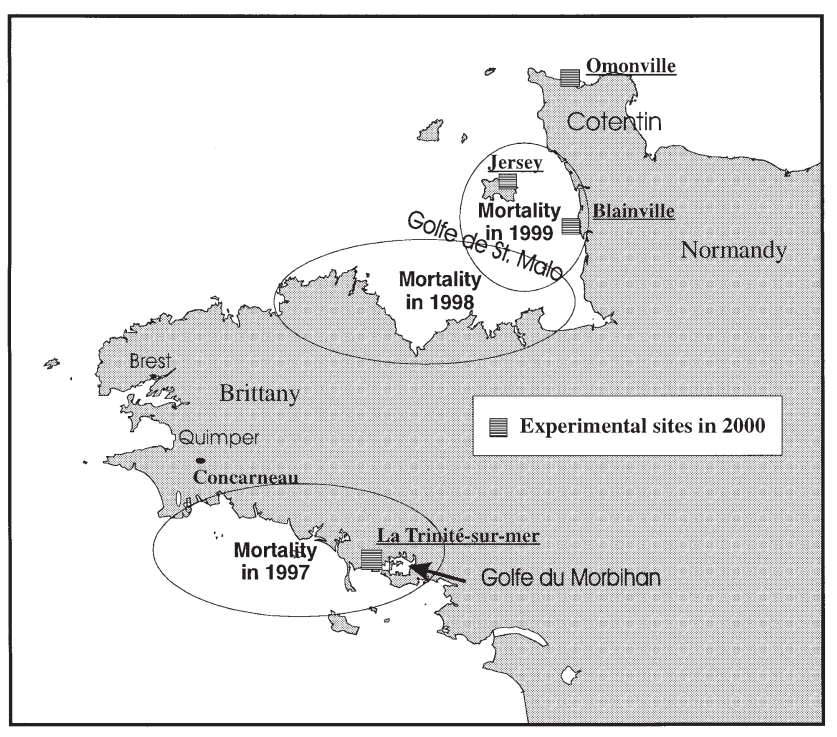

Fig. 1. Areas along the French coast affected by mass mortality of Haliotis tuberculata, and experimental sites in 2000

ity reached $85 \%$ by the end of September (Fig. 2). Apart from some occurrences of white pustules on the foot, no other signs, nor any abnormal behaviour were apparent before death.

Numerous diseases affecting abalone have been described (Bower 2000). A parasite, Perkinsus olseni, infects several Australian abalone species and is the only agent recognized as a serious pathogen for Haliotis spp. by the Office International des Epizooties $(2001)^{1}$ (Lester 1981). However, in 1983 bacteria, especially Vibrio spp. were already suspected to infect abalone juveniles (Elston \& Lockwood 1983). More recently Li et al. (1998) isolated V. fluvialis II, which caused pustule formation and mortality in the abalone $H$. discus hannai Dalian in China. V. carchariae is responsible for disease and mortalities among Japanese abalone, Sulculus diversicolor supratexta (Nishimori et al. 1998), and a Rickettsia-like prokaryote is suspected to be one of the causes of foot-withering syndrome among the wild black abalone Haliotis cracherodii in California, USA (Gardner et al. 1995, Moore et al. 1999). Other parasites that infect different species of abalone include a coccidian (Friedman 1991) and Labyrinthuloides haliotidis (Bower 1987). Polychaetes frequently infest abalone under culture (Ruck \& Cook 1998). Virus-like particles were detected in abalone Nordotis discus discus associated with amyotrophia of the mantle and foot, and mortality in juveniles at a nursery in Japan (Nakatsugawa et al. 1999). Previously, shells of H. tuberculata, in France, were only known to be infested by the sponge Cliona celata and polychaetes

${ }^{1}$ International Aquatic Animal Health Code. www.oie.int/ eng/normes/fcode/a_summry.htm of the genus Polydora (Clavier 1992). No soft-tissue pathogens had been reported.

In 1998, moribund and 'healthy' abalone were collected in the natural environment in France; 60 individuals of different sizes were sampled and examined by histology and bacteriology. First observations showed no protistan parasitic agents such as Perkinsus olseni. Two individuals showed 1 trematode each, encysted in the mantle; intensities were too low to be responsible for mortality. Bacteria were often found in association with tissue necrosis, but this could not be considered significant in moribund abalone since Vibrio spp. isolated from these tissues were too diversified to be primary aetiological agents of the disease.

After the disease appeared in the SMEL hatchery in 1999, its study became easier and permitted isolation of the causative agent, its identification and determination of its pathogenicity. In 2000, abalone stocks placed in 4 sites on the coast were monitored to observe mortality and to identify the causative agent.

\section{MATERIALS AND METHODS}

Abalone and general observations. In 1999, abalone about $100 \mathrm{~mm}$ in shell length were transferred from an area without reported mortality (north of Cotentin, France) to the farm of SMEL. Before and during mortality in tanks at SMEL, behaviour and external appearance were observed daily. The bodies of recently dead abalone were removed from the shell and their anatomical appearance was recorded. In 2000, an experiment in the natural environment was performed with abalone from the Cotentin area and also from Jersey (see last subsection of 'Experiments' below).

Bacteriology. Dead abalone from the first experiment (see below) were dissected and samples of different tissues including haemolymph from the cardiac sinus, muscle and mucus gland, were collected under sterile conditions. An aliquot of sample was directly observed by light microscopy to verify if individuals were infected or not: all tissues of infected abalone were invaded by abundant and motile bacteria while in healthy individuals no bacteria could be observed. Then the samples were plated on Marine Agar (Difco). A first observation of the plates incubated at $20^{\circ} \mathrm{C}$ was made after $48 \mathrm{~h}$, and a second observation $5 \mathrm{~d}$ later. The most prevalent colony types were subcultured and stored at $4^{\circ} \mathrm{C}$ or at $-80^{\circ} \mathrm{C}$. Generally only 1 type was present and very abundant except, occasionally, in samples of the mucus gland.

The dominant bacteria were first tested on $\mathrm{O} / \mathrm{F}$ medium (Merck) for respiratory type and TCBS agar (Difco) for growth. They were then observed by light microscopy, suspended in a sterile water supplement 
with $2 \% \mathrm{NaCl}$ and identified with the API 20E system (Biomerieux). Some additional characters including Gram-stain, growth at different temperatures $(4,37$, $45^{\circ} \mathrm{C}$ ) in marine broth (Difco), and oxidase and catalase activities were examined. To complete the phenotypic characters, the GN plate (Biolog) was used according to the procedure recommended by the manufacturer. The GN plate tests the ability of a bacterium to utilize a panel of 95 different carbon sources.

For inoculation of abalone, the predominant isolate (named ORM4) from moribund and dead abalone was cultured in $50 \mathrm{ml}$ marine broth (Difco), at $20^{\circ} \mathrm{C}$ overnight. Bacterial cells were centrifuged $(6000 \times g$ for $10 \mathrm{~min})$, rinsed with sterile sea water (SSW), resuspended in SSW, and then counted by plating on marine agar after appropriate dilution.

Phylogenetic analyses using DNA sequencing. The method used for amplification was as described by Gauthier et al. (1995). Briefly, after extraction of DNA, 16S rDNA was amplified with universal primers AS and S17 (Escherichia coli positions 8-28 and 1496-1505, respectively), and the amplicon was purified by precipitation. After checking of amplicon by agarose gel electrophoresis, it was sent to Genome Express Company (Grenoble, France) to be sequenced with an automated DNA sequencer. The 16S rDNA gene sequence was aligned with the nearest reference sequences, obtained from databases, by the CLUS-TAL W programme (Dnastar).

Phylogenetic trees were built using the Phylowin programme developed by Galtier et al. (1996). Three methods were employed: neighbour-joining, maximumparsimony, and maximum-likelihood.

Experiments. Five experiments were carried out as follows:

Expt 1-influence of temperature: Abalone $(4$ to $5 \mathrm{~cm}$ in length) that had been in contact with diseased abalone, were placed in six 201 tanks with aeration and complete renewal of sea water every other day, but without feeding. Each tank contained 10 abalone. The temperature was maintained at $10^{\circ} \mathrm{C}$ (2 tanks, first series), $15^{\circ} \mathrm{C}$ ( 2 tanks, second series) and $20^{\circ} \mathrm{C}$ (2 tanks, third series) for $12 \mathrm{~d}$. The temperature then was increased to $20^{\circ} \mathrm{C}$ in tanks of the first and second series and maintained for $15 \mathrm{~d}$.

Expt 2-cohabitation challenge: In order to provoke the disease, apparently healthy abalone from an unaffected area (north of Cotentin) were transferred to an experimental facility of SMEL. Three batches of 15 apparently healthy abalone ( 7 to $9 \mathrm{~cm}$ in length) each were placed in
3 recirculating sea water tanks at $18 \pm 1^{\circ} \mathrm{C}$, with a water renewal of $20 \% \mathrm{~d}^{-1}$; 2 of the tanks had recently contained abalone with a record of mortality and 1 tank (control) had previously contained abalone without mortality. Abalone were fed on red algae, Palmaria palmata, ad libitum. The saturation rate of oxygen was maintained near $100 \%$ and dead individuals were removed daily. The experiment lasted $19 \mathrm{~d}$.

Expt 3-inoculation challenge: Two abalone that had just died were dissected and pieces of the foot, digestive tract, and haemolymph were collected, mixed with $20 \mathrm{ml}$ of sterile saline solution $(0.9 \% \mathrm{NaCl})$ and ground with a Stomacher. After sedimentation, the supernatant was separated from the residue. The same process was applied to 3 apparently healthy abalone from an unaffected area.

The supernatant $(0.5 \mathrm{ml})$ from diseased individuals was inoculated into the foot of 3 different batches of 8 apparently healthy abalone. The 3 treatment batches included supernatant that was filtered as follows: (1) unfiltered, (2) $1.2 \mu \mathrm{m}$ filtration (nitrate-cellulose membrane, Millipore) and (3) $0.2 \mu \mathrm{m}$ filtration (polycarbonate membrane, Millipore).

Two controls consisted of 8 abalone each, inoculated with unfiltered supernatant of ground samples of apparently healthy individuals or a saline solution $(0.9 \% \mathrm{NaCl})$, respectively.

The abalone of each treatment were held in the same $30 \mathrm{ltank}$, at $18 \pm 1^{\circ} \mathrm{C}$ and were not fed for $2 \mathrm{wk}$. The sea water was totally renewed daily.

Expt 4-bacterial culture challenge: Eight batches of 10 apparently healthy abalone each were held in 30 1 tanks ( 1 tank per batch), at $18 \pm 1^{\circ} \mathrm{C}$ without food, and were dosed with the suspected bacterium as follows: (1) injection of $0.5 \mathrm{ml}$ containing $5 \times 10^{8}$ bacteria (2 batches), (2) exposure to $10^{5} \mathrm{ml}^{-1}$ bacterial cells in the surrounding sea water for $24 \mathrm{~h}$ (2 batches), (3) exposure to sea water in which abalone injected during the

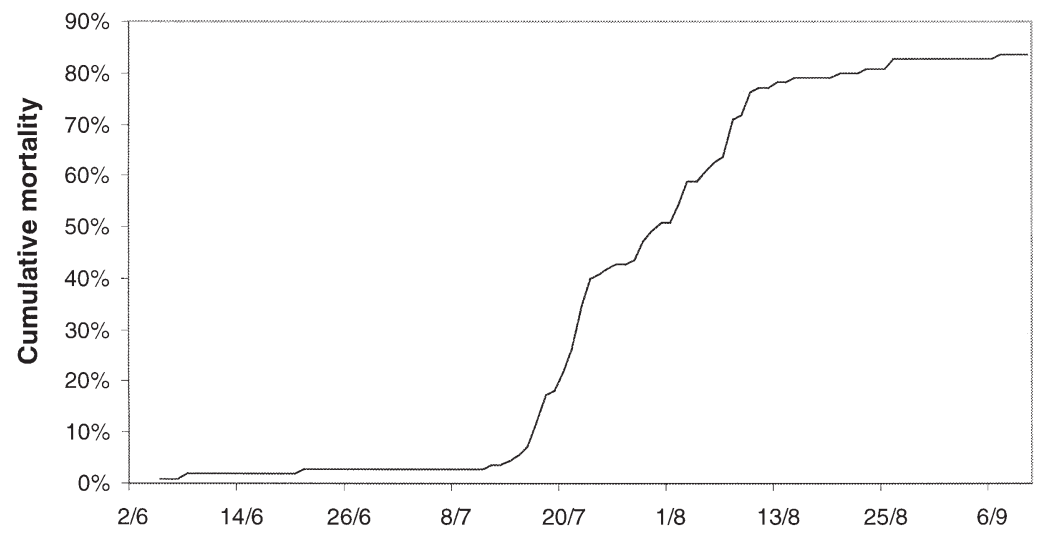

Fig. 2. Haliotis tuberculata. Cumulative mortality in the SMEL abalone farm during summer 1999 (abscissa shows day/month) 


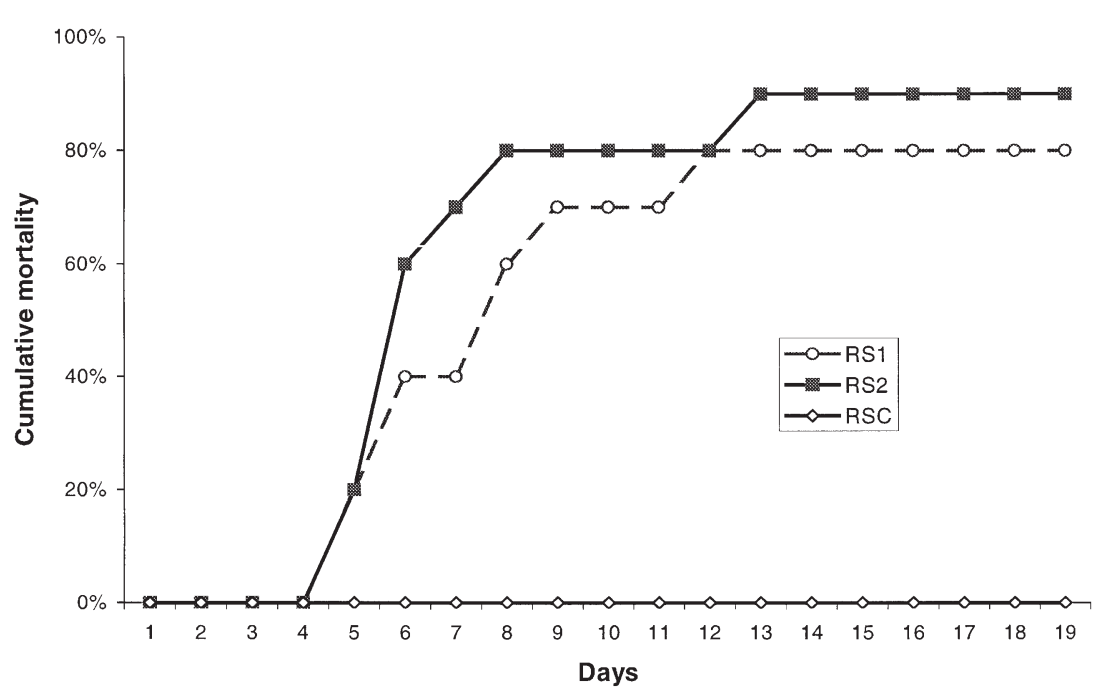

Fig. 3. Haliotis tuberculata. Natural contamination in recycling sea water systems of the abalone farm. RS1, RS2: previously contaminated systems, RSC: noncontaminated system
Abalone were always immersed and received macroalgae (Palmaria palmata or Laminaria digitata) as food, which was renewed every second week at all sites.

Temperature was monitored at Blainville and La Trinité by electronic sensors and the facilities were visited at least once a week in France and once every 2 wk in Jersey. Only recently dead abalone were dissected. Samples of tissues (foot and mucus gland) were examined by light microscopy and plated on marine agar. After $3 \mathrm{~d}$ of incubation, 2 or 3 representatives of the dominant colony were identified by phenotypic characters: gram staining, fermentation products and API 20E results.

\section{RESULTS}

experiment had been held, (2 batches) and (4) no treatment ( 2 batches).

Expt 5-causative agent in the natural environment: In the north of Cotentin, no mortality had been observed but the temperature of the sea water, which remained below $18^{\circ} \mathrm{C}$ throughout the year, did not favor disease expression. Therefore, to ensure that abalone were not healthy carriers of the disease, 3 experiments of 1 mo duration were performed in December 1999, and in March and June 2000. For each experiment, 10 healthy abalone ranging in size from 65 to $90 \mathrm{~mm}$ were caught in this area and placed in a 401 tank with renewal of sea water (50\% every other day) and aeration, but without feeding. The temperature was maintained at $19 \pm 1^{\circ} \mathrm{C}$. No mortality was observed during the 3 experiments, except that 1 or 2 individuals per experiment died during the first few days after the transfer.

Abalone from the same stock used for the last monitoring experiment were placed at 3 different sites in June 2000 (Fig. 1): On the north-east of the Cotentin peninsula, Omonville la Rogue (control site), 100 abalone were held in 2 perforated plastic casks. In the Golfe de St Malo, near Blainville, 87 abalone were set in a concrete tube closed at the ends by wire and plastic netting. On the south coast of Brittany, at the IFREMER station of La Trinité-sur-Mer (Golfe du Morbihan), 80 abalone were placed in a $3 \mathrm{~m}^{3}$ tank, the water of which was renewed twice a week with pumped sea water; 20 others were held in a lobster pot suspended in sea water close to the station.

At an additional site, Jersey (Golfe de St Malo), about 100 abalone were caught around the island and placed in different structures at Bailhache Rock (west of the island).

\section{Influence of temperature}

All abalone maintained at 10 or $15^{\circ} \mathrm{C}$ survived, whereas $50 \%$ of those maintained at $20^{\circ} \mathrm{C}$ died during the first $12 \mathrm{~d}$. In the second stage of these trials (15 d), when the temperature was increased to $20^{\circ} \mathrm{C}$ in the first and second series, limited mortality occurred $(20 \%)$. In the third series, in which the temperature remained constant, mortality continued, reaching $65 \%$ by the end of the study.

\section{Isolation of bacteria}

In the second cohabitation experiment, the abalone started to die after $3 \mathrm{~d}$ in both recirculating systems that had contained diseased abalone (Fig. 3). Some challenged abalone showed signs of white pustule development. No mortality occurred in the control system. Five abalone that had just died were dissected, and samples of tissue (cardiac sinus, foot muscle and mucus gland) were observed by light microscopy in phase contrast and streaked on marine agar. Microscopic observation showed a great number of motile bacteria. On the agar plate, a dominant type of colony appeared within 24 to $48 \mathrm{~h}$. The pustules from 1 individual also contained the same type of colony. Certain colonies from 3 individuals were identified; these grew on TCBS agar (green colony) and were facultative anaerobes. They shared the same characters in the API 20E test (Table 1). The type strain was named ORM4. 


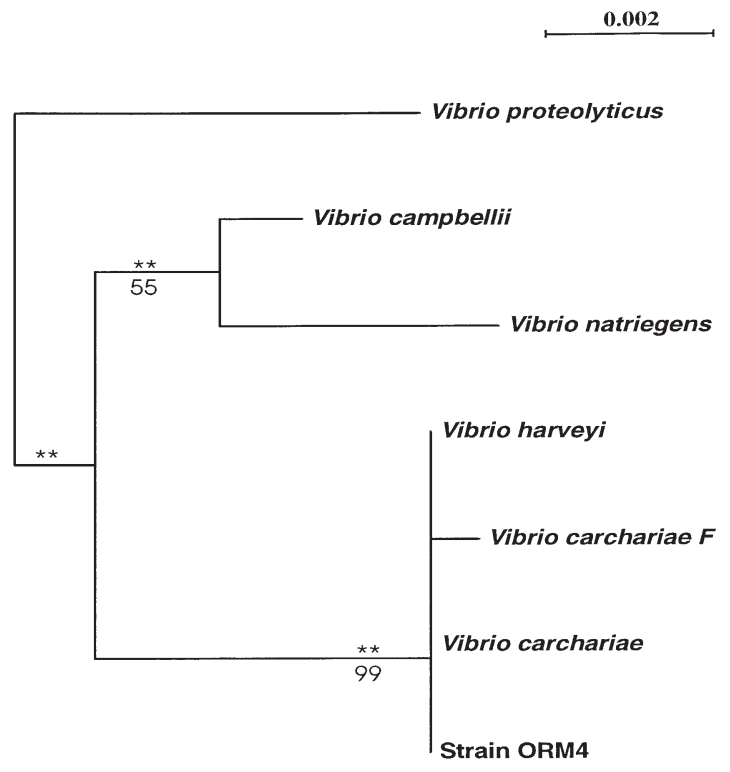

Fig. 4. Vibrio spp. Phylogenetic relationship of Strain ORM 4 with other Vibrio species. An unrooted phylogenetic tree was obtained by performing neighbour-joining analysis. **: branches significantly positive at the $\mathrm{p}<0.01$ level determined by maximum-likelihood method; same topology was obtained using the maximum-parsimony method. Values under the lines correspond to percentages obtained by a bootstrap analysis when the maximum-parsimony method was used. Accession numbers of sequences used as reference strains for phylogenetic analyses = X74692 (V. campbellii); X74706 (V. harveyi); X74693 (V. carchariae); AF 134581 (V. carchariae F); $\mathrm{X} 74723$ (V. proteolyticus); X74714 ( $V$. natriegens). Scale bar = number of accumulated changes per nucleotide

\section{Identification of the Vibrio sp.}

The sequence of ORM4 was similar at $99.6 \%$ to the reference strain of Vibrio carchariae (American Type Culture Collection, ATCC 35 084). The few differences (5 bases) may have been due to sequencing errors (missing or undetermined bases). Phylogenetic analyses showed a close relationship between Strain ORM4, $V$. carchariae and V. harveyi (Fig. 4); V. carchariae is a subspecies of $V$. harveyi according to Pedersen et al. (1998).

Strain ORM4 and Vibrio carchariae ATTC 35084 (Yii et al. 1997) differed in some phenotypic characters, especially sucrose utilisation. In comparison with the reference strain ATTC 35084, ORM 4 used Tween $40, \beta$-methyl-glucosidase $\mathrm{D}$-alanine, L-proline, monomethyl succinate, $D_{1} \mathrm{~L}_{1}-\alpha$-glycerol phosphate but not sucrose, alaninamide, or L-pyroglutamic acid (Table 1).

Strain ORM 4 was similar to Vibrio carchariae isolated from diseased abalone in Japan in its inability to use or ferment sucrose. Nevertheless, for our strain, gelatinase and ornithine decarboxylase were positive and the Voges-Proskauer reaction was negative. No data on the Japanese strain are available to compare utilization of organic substrates.

Table 1. Phenotypic traits of Strain ORM4 in comparison with reference strain of Vibrio carchariae (TK1091: data from Nishimori et al. 1998) and strain of $V$. carchariae isolated from a Japanese abalone (ATCC 35084: data from Yii et al. 1997). +: present; -: absent; $\mathrm{G}$ = green colony; $\mathrm{Y}=$ yellow colony; nd: not determined; v: variable; w: weak. (Additional positive characters of Biolog GN plate: utilisation of organic substrates by Strain ORM4 $=\alpha$-cyclodextrine, dextrine, glycogen, Tween 40, Tween 80, N-acetyl-D-galactosamine, N-acetylglucosamine, cellobiose, D-fructose, D-galactose, $\alpha$-D-glucose, maltose, D-mannitol, D-mannose, $\beta$-methyl-D-glucoside, D-psicose, D-trehalose, methyl-pyruvate, monomethyl-succinate, acetic acid, cis-aconitic acid, citric acid, formic acid, D-gluconic acid, D-glucuronic acid, $\alpha$-keto glutaric acid, propionic acid, D,L-lactic acid, succinic acid, bromo-succinic acid, glucuronamid, D-alanine, L-alanine, L-glycinalanine, L-asparagine, L-aspartic acid, L-glutamic acid, L-glycyl-aspartic acid, L-glycyl-glutamic, L-proline, D-serine, L-serine, L-threonine, inosine, uridine, thymidine, glycerol, D,L- $\alpha$-glycerolphos-

phate, glucose- 1 phosphate and glucose- 6 phosphate)

\begin{tabular}{|c|c|c|c|}
\hline Trait & $\begin{array}{l}\text { Vibrio } \\
\text { ORM4 }\end{array}$ & $\begin{array}{c}\text { Vibrio } \\
\text { Carchariae } \\
\text { (TK1091) }\end{array}$ & $\begin{array}{c}\text { Vibrio } \\
\text { carchariae } \\
\text { (ATCC 35084) }\end{array}$ \\
\hline Gram & - & - & - \\
\hline Motility & + & + & + \\
\hline Luminescence & - & - & - \\
\hline Growth on TCBS & $\mathrm{G}$ & G & $\mathrm{Y}$ \\
\hline Catalase & + & + & + \\
\hline $4^{\circ} \mathrm{C}$ & - & nd & - \\
\hline $37^{\circ} \mathrm{C}$ & + & nd & + \\
\hline $45^{\circ} \mathrm{C}$ & - & nd & - \\
\hline $\begin{array}{l}\text { API20E ( } 2 \% \mathrm{NaCl} 24 \text { h) } \\
\text { oxidase }\end{array}$ & + & + & + \\
\hline$\beta$-galactosidase & - & - & - \\
\hline Arginine dehydrolase & - & - & - \\
\hline Lysine decarboxylase & + & + & + \\
\hline Ornithine decarboxylase + & $+(48 \mathrm{~h})$ & - & + \\
\hline Citrate utilisation & $\mathrm{v}(\mathrm{w})$ & $+(\mathrm{w})$ & $+(\mathrm{w})$ \\
\hline $\mathrm{H}_{2} \mathrm{~S}$ production & - & - & - \\
\hline Urease production & - & - & + \\
\hline Tryptophane desaminase & - & - & - \\
\hline Indole production & + & + & + \\
\hline Acetoin production & - & $\mathrm{v}$ & - \\
\hline Gelatine hydrolysis & + & - & $\mathrm{v}$ \\
\hline Fermentation of glucose & + & + & + \\
\hline Mannitol & + & + & + \\
\hline Inositol & - & - & - \\
\hline Sorbitol & - & - & - \\
\hline Rhamnose & - & - & - \\
\hline Sucrose & - & - & + \\
\hline Melibiose & - & - & - \\
\hline Amygdaline & + & + & + \\
\hline Arabinose & - & - & - \\
\hline Reduction of $\mathrm{NO}_{3} \rightarrow \mathrm{NO}_{2}$ & + & + & + \\
\hline
\end{tabular}




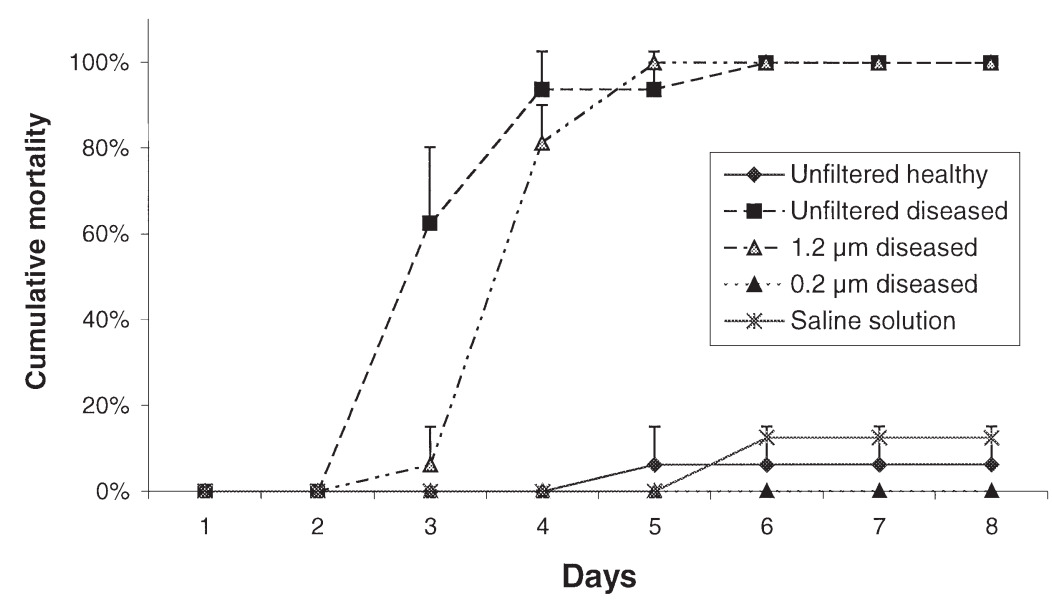

Fig. 5. Haliotis tuberculata. Mortality (means $\pm \mathrm{SD}$ ) of abalone challenged by inoculation of ground tissue samples in the foot. Unfiltered healthy: $0.5 \mathrm{ml}$ of healthy abalone tissues; Unfiltered diseased: $0.5 \mathrm{ml}$ of moribund abalone tissues; $1.2 \mu \mathrm{m}$ diseased: $0.5 \mathrm{ml}$ of previous sample filtered through $1.2 \mu \mathrm{m}$ membrane; $0.2 \mu \mathrm{m}$ diseased: $0.5 \mathrm{ml}$ of previous sample filtered through $0.2 \mu \mathrm{m}$ membrane; Saline solution: $0.5 \mathrm{ml}$ of $0.9 \% \mathrm{NaCl}$

\section{Experimental reproduction of the disease}

Tissue inoculation challenge

In the third experiment, the abalone that received unfiltered ground tissue inocula from diseased individuals began to die on the first day after inoculation (Fig. 5). For abalone inoculated with $1.2 \mu \mathrm{m}$-filtered ground tissues, first mortalities were observed after $2 \mathrm{~d}$. The $0.2 \mu \mathrm{m}$-filtered inoculum did not induce mass mortality nor did the inoculum prepared with tissues from healthy abalone or the inoculum of saline solution. Of 3 individuals out of 32 that died in the last 2 groups, 1 was infected by bacteria identified as Vibrio carchariae.

Four diseased individuals were examined in the first inoculated batch and 5 in the second. All were heavily infected by a Vibrio identical phenotypically to Strain ORM4.

\section{Bacterial culture challenge}

In the fourth experiment (Fig. 6), abalone directly inoculated with bacteria or exposed to tank water inoculated with ORM4 began dying after $2 \mathrm{~d}$. In both cases, all individuals died quickly, whereas the abalone which received sea water in which diseased abalone had been held died $4 \mathrm{~d}$ post-exposure, and some abalone remained alive until the end of the test. Control abalone suffered up to $25 \%$ mortality. Two or 3 dead abalone of each batch were examined. All of these, including 2 control individuals, were infected by Vibrio carchariae.

\section{Mortality in the open sea}

The first mortalities were observed in the tank of the laboratory at La Trinité: 5 abalone died between June 28 and July 13. The temperature during this period varied from 16.5 to $18.5^{\circ} \mathrm{C}$. Tissues from 2 abalone were recovered for examination. Observation by light microscopy showed that the tissues were invaded by bacteria. Only 1 type of colony grew in abundance on marine agar and TCBS (green colony). Phenotypic characters of this colony were identical to those of Vibrio carchariae isolated the previous year. All abalone in the tank were subsequently discarded to avoid further proliferation of the pathogen, which could increase the contamination in the open sea since the outflow was not treated. In the outdoor pot near the IFREMER station, only 2 abalone died, 1 just after transfer and the other in September. They could not be examined because the tissues were decayed.

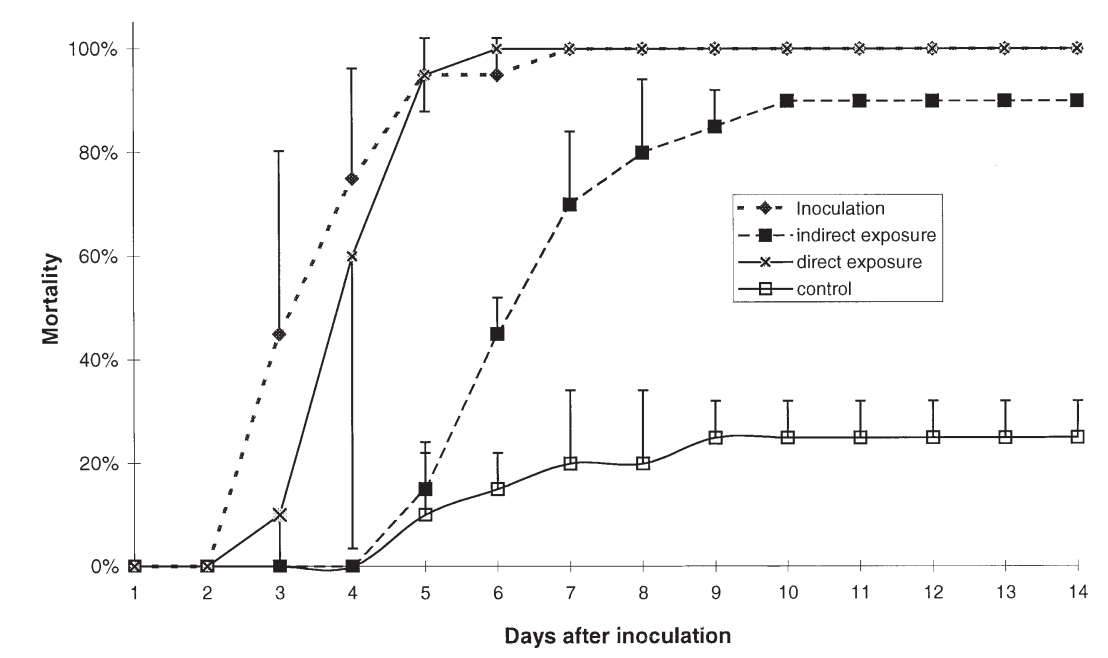

Fig. 6. Haliotis tuberculata. Mortality (means $\pm \mathrm{SD}$ ) of abalone challenged by inoculation or by exposure to medium of pathogenic bacterium. Inoculation: inoculation of $5 \times 10^{8}$ cells per abalone; direct exposure: exposure to sea water containing $10^{5}$ cells ml ${ }^{-1}$ of Vibrio carchariae for $24 \mathrm{~h}_{\text {; }}$ indirect exposure: abalone exposed to sea water contaminated by treatment 'Inoculation'; control: no inoculation 
In Blainville, 71 of 87 abalone ( $84 \%$ mortality) died between September 1 and 13; here, the temperature had been 18 to $19^{\circ} \mathrm{C}$ since mid-July. Eight abalone, which seemed to have just died and still had intact tissues, were dissected and samples of haemolymph and foot muscle were plated on marine agar and TCBS: all individuals were invaded by Vibrio carchariae phenotypically identical to ORM4.

In Jersey, the experiment was stopped at the end of August, although the abalone had not yet suffered mortality and although the temperature was still above $18^{\circ} \mathrm{C}$. In the control site (Omonville), no mortality occurred in any abalone cultured at this site until the end of experiment (end of August).

\section{DISCUSSION}

The abundance of 1 dominant type of bacterium in recently dead abalone implicated this bacterium in their mortality. Experiments (Table 2) demonstrated the virulence of this isolate, although sometimes limited mortality did occur in control batches. In some cases, Vibrio carchariae was isolated from control abalone, but in other cases the abalone were probably injured during transfer from the sea to the experimental containers.

Mortality depended on incubation temperature. In the first experiment mortality did not occur at 10 and $15^{\circ} \mathrm{C}$. Another challenge experiment, not reported here, failed because mortality ceased when the tem- perature fell below $17^{\circ} \mathrm{C}$. As soon as the temperature was stabilised above $17^{\circ} \mathrm{C}$, mortality rose again. This may be related to the temperature preference of Vibrio carchariae, which grows above $37^{\circ} \mathrm{C}$ but not at $4^{\circ} \mathrm{C}$. On the other hand, the metabolism of Haliotis tuberculata is more active and its growth faster when the temperature reachs $20^{\circ} \mathrm{C}$ or more in hatcheries (Lopez et al. 1998). However, in the natural environment, its optimal temperature seems to lie below $18^{\circ} \mathrm{C}$ (McBride et al. 2000). The physiological status of the abalone at high temperatures may make it more susceptible to infection.

Previous attempts to find a pathogenic agent in healthy abalone, or even in groups of abalone affected by mortality, have failed (Thébault 1999), probably due to the rapidity of infection and the lack of outward signs, except for white pustules which sometimes appear just before death.

This disease resembles that described in the Japanese abalone Sulculus diversicolor supratexta (Nishimori 1998), especially since the pathogen strain belongs to the same species. Nevertheless, infected French abalone did not exhibit the same symptoms. White spots on the foot was the characteristic sign of disease in the Japanese abalone and mortality was less severe (15\% of the stock). In our case, about $85 \%$ of the abalone died after exposure to sea water containing Vibrio carchariae.

French and Japanese pathogens could be distinguished from the Vibrio harveyi and V. carchariae strains by their non-utilization of sucrose. Both strains

Table 2. Haliotis tuberculata. Experiments performed to find the causative agent of abalone mortalities

\begin{tabular}{|c|c|c|}
\hline & Results & $\begin{array}{l}\text { Isolation or re-isolation } \\
\text { of bacteria from dead } \\
\text { abalone }\end{array}$ \\
\hline \multicolumn{3}{|l|}{ Expt 1} \\
\hline Influence of temperature on mortality & $\begin{array}{l}\text { After } 12 \mathrm{~d} \text { no mortality at } 10 \text { and } 15^{\circ} \mathrm{C} \text {, } \\
50 \% \text { mortality at } 20^{\circ} \mathrm{C}\end{array}$ & None \\
\hline \multicolumn{3}{|l|}{ Expt 2} \\
\hline $\begin{array}{l}\text { Assay of reproduction of disease by placing } \\
\text { healthy abalone in contaminated area and } \\
\text { in area without mortality }\end{array}$ & Disease only in contaminated area & $\begin{array}{l}\text { Dominant bacteria } \\
\text { (Type Strain ORM4) } \\
\text { is Vibrio carchariae }\end{array}$ \\
\hline \multicolumn{3}{|l|}{ Expt 3} \\
\hline $\begin{array}{l}\text { Transmission of disease by injection of ground } \\
\text { tissues of diseased abalone: raw, filtrate at } 1.2 \text { and } \\
0.2 \mu \mathrm{m} \text {; control: ground tissues of healthy abalone }\end{array}$ & $\begin{array}{l}\text { Mortality in abalone injected with } \\
\text { raw inoculum and } 1.2 \mu \mathrm{m} \text { filtrate }\end{array}$ & $\begin{array}{l}\text { Vibrio carchariae (pheno- } \\
\text { type identical to ORM4) }\end{array}$ \\
\hline \multicolumn{3}{|l|}{ Expt 4} \\
\hline $\begin{array}{l}\text { Inoculation of Vibrio carchariae by injection } \\
\text { or by exposure }\end{array}$ & $\begin{array}{l}\text { All batches in contact with Vibrio } \\
\text { carchariae exhibited mass mortality }\end{array}$ & $\begin{array}{l}\text { Vibrio carchariae (pheno- } \\
\text { type identical to ORM4) }\end{array}$ \\
\hline \multicolumn{3}{|l|}{ Expt 5} \\
\hline $\begin{array}{l}\text { Study of mortality at open sites: healthy abalone } \\
\text { were placed during summer at } 4 \text { sites in Brittany } \\
\text { and Jersey }\end{array}$ & Mortality at 2 sites & $\begin{array}{l}\text { Vibrio carchariae (pheno- } \\
\text { type identical to ORM4) }\end{array}$ \\
\hline
\end{tabular}


are very closely related, but differ in some phenotypic characters such as ornithine decarboxylase, gelatinase and acetone production (positive in the present study).

The disease of Haliotis tuberculata, in France, has some common features with the disease of Haliotis discus hannai described in China (Li et al. 1998). Indeed, Vibrio fluvialis II provoked high mortality (50 to $60 \%$ ) in Chinese abalone, with a similar, but more frequent appearance of white pustules on the foot. Temperature was probably important since the disease occurred at $20^{\circ} \mathrm{C}$ and $V$. fluvialis II shows poor growth at $15^{\circ} \mathrm{C}$. Although no genotypic analysis was performed, several phenotypic traits clearly distinguished $V$. fluvialis II from V. carchariae: arginine hydrolase, arabinose fermentation and gelatinase were different.

It would be interesting to compare the characters and virulence of these different strains or species of Vibrio in the same place and in the same species of abalone. Such an experiment would reveal whether the pathogen infects only 1 host species or several-an important consideration in preventing the spread of disease from one area to another. The introduction of exotic species can provoke severe disease in an autochthonous and closely related host species. In the case reported here, additional hypotheses are possible such as transport of the pathogen by another marine animal, or climatic change, or both.

Vibrio carchariae can infect a wide spectrum of marine animals such as prawns, sharks, sea bream, sea bass and turbot (Pedersen et al. 1998). The taxonomy based on ribotyping shows a great diversity of strains, and probably each strain is adapted only to its particular host. However without experimentation, it is impossible to know if the same strain can induce mortality in other species.

Vibrio carchariae is suspected to be the causative agent of the French abalone disease occurring in the natural environment since 1997. Some features of the disease in nature, such as the outbreak at temperatures above $17^{\circ} \mathrm{C}$, the level of mortality, and the difficulty of finding moribund individuals were similar to those in the affected hatchery, leading to the hypothesis of the same aetiology. In 2000, the experiment with abalone placed in different areas (in the Golfe du Morbihan and the Golfe de St Malo) confirmed this hypothesis. In both locations abalone died when temperatures reached at least $18^{\circ} \mathrm{C}$, and Vibrio carchariae was easily isolated from the tissues of recently dead individuals. Thus, it is possible to relate mass mortality of abalone in the natural environment to the occurrence of this pathogen.

A small number of abalone (about $15 \%$ ) in the natural environment or in the SMEL farm appear to be resistant to the bacterial infection. Although all abalone are sensitive to exposure at high levels of concentration or inoculation, this resistance could be important for restoring the stock, should it have a genetic origin transmissible to descendants. Recently, a great number of small abalone were observed in the sites affected by the disease. These are descendants of survivors, and perhaps are more resistant. A challenge experiment could determine the level of resistance of this new generation.

Such a study would have to comprise different experiments with exposure to different inoculate concentrations in sea water to establish a dose-response. Bacterial concentrations at every stage must be determined, especially from healthy and unhealthy tissues and filtrates. Further work is also planned to determine and synthesise oligonucleotides specific to this strain of Vibrio carchariae to permit its discrimination from $V$. harveyi and other $V$. carchariae strains by PCR. This olidonucleotide could be used for epidemiological studies, monitoring of farm-reared abalone, and for determining the infection route through in situ hybridization.

Acknowledgements. We gratefully thank S. Bossy (Fisheries Officer, Research \& Development, Department of Agriculture \& Fisheries, State of Jersey) for his help in the performance of experiments in the natural environment.

\section{LITERATURE CITED}

Basuyaux O (1997) Etude et modélisation des paramètres physico-chimiques sur la croissance en élevage de l'ormeau (Haliotis tuberculata) en circuit semi-fermé. Thèse de 3ième cycle de l'Université de Caen, France

Bower SM (1987) Labyrinthuloides haliotidis n. sp. (Protozoa: Labyrinthomorpha), a pathogenic parasite of small juvenile abalone in a British Columbia mariculture facility. Can J Zool 65:1996-2007

Bower SM (2002) Infectious diseases of abalone and risks associated with transplantation. Can Spec Publ Fish Aquat Sci (in press)

Clavier J (1992) Infestation of Haliotis tuberculata shells by Cliona celata and Polydora species. In: Guzman del Proo SA, Tegner MJ, Shepherd SA (eds) Proceedings of the 1st International Symposium on Abalone in La Paz, Mexico, 1989. Dept of Fisheries, Adelaide, p 16-20

Elston R, Lockwood GS (1983) Pathogenesis of vibriosis in cultured juvenile red abalone, Haliotis rufescens. J Fish Dis 6: 111-128

Friedman CS (1991) Coccidiosis of California abalone, Haliotis sp. J Shellfish Res 10:236 (Abstract)

Galtier N, Gouy M, Gautier C (1996) SeaView and Phylo_win, two graphic tools for sequence alignment and molecular phylogeny. Comput Appl Biosci 12:543-548

Gardner GR, Harshbarger JC, Lake JL, Sawyer TK, Price KL, Stephenson MD, Haaker PL, Togstad HA (1995) Association of prokaryotes with symptomatic appearance of withering syndrome in black abalone Haliotis cracerodii. J Invertebr Pathol 66:111-120

Gauthier G, Gauthier M, Christen R (1995) Phylogenetic analysis of the genera Alteromonas, Shewanella, and Moritella using genes coding for small-subunit rRNA 
sequences and division of the genus Alteromonas into two genera Alteromonas (emended) and Pseudoaltermonas gen., nov., and proposal of twelve new species combinations. Int J Syst Bacteriol 45:755-761

Lester RJG (1981) A new Perkinsus species (Apicomplexa, Perkinsa) from abalone Haliotis ruber. J Invert Pathol 37: 181-187

Li T, Ding M, Zhang J, Xiang J, Liu R (1998) Studies on the pustule disease of abalone (Haliotis discus hannai Ino) on the Dalian coast. J Shellfish Res 17:707-711

Lopez LM, Tyler PA, Viana MT (1998) The effect of temperature and artificial diets on growth rates of juvenile Haliotis tuberculata (Linnaeus, 1758). J Shellfish Res 17:657-662

McBride SC, Rotem E, Ben-Ezra D, Shipgel M (2000) Evaluation of seasonal bioenergetics of Haliotis fulgens and Haliotis tuberculata. J Shellfish Res 19:525 (Abstract)

Moore JD, Robbins, TT Friedman CS (1999) Withering syndrome in farmed red abalone, Haliotis rufescens. J Shellfish Res 18:319 (Abstract)

Nakatsugawa T, Nagai T, Hiya $K$, Nishizawa T, Muroga $K$

Editorial responsibility: Albert Sparks,

Seattle, Washington, USA
(1999) A virus isolated from juvenile Japanese black abalone Nordotis discus discus affected with amyotrophia. Dis Aquat Org 36:159-161

Nishimori E, Hasegawa O, Numata T, Wakabayashi H (1998) Vibrio carchariae causes mass mortalities in Japanese abalone, Sulculus diversicolor supratexta. Fish Pathol 33: 495-502

Pedersen K, Verdonck L, Austin B, Austin DA, Blanch AR, Grimont PA, Jofre J, Kobalvi S, Larsen JL, Tiainen T, Vigneulle, M, Swings J (1998) Taxonomic evidence that Vibrio carchariae (Grimes et al. 1985) is a junior synonym of Vibrio harveyi (Johnson \& Shunk, 1936) Baumann et al. 1981. Int J Syst Bacteriol 48:749-758

Ruck KR, Cook PA (1998) Sabellid infestations in the shells of South African molluscs: implications for abalone mariculture. J Shellfish Res 17:693-699

Yii KC, Yang TI, Lee KK (1997) Isolation and characterisation of Vibrio carchariae, a causative agent of gastro-enteritis in the groupers, Epinephelus coioides. Curr Microbiol 35: 109-115

Submitted: January 5, 2001; Accepted: November 23, 2001 Proofs received from author(s): May 28, 2002 